CATALLAXY

Volume 2 Issue 2 December 2017

e-ISSN 2544-090X

¿ www.catallaxy.pl

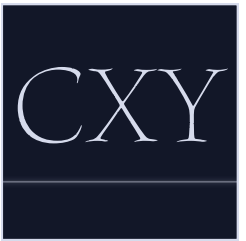

Oryginalny artykut naukowy

otrzymano: 25.10.2017 / zaakceptowano: 01.12.2017 / opublikowano online: 31.12.2017

Pogorzelski, A. (2017). Bezpieczeństwo energetyczne Polski w latach 2010-2015: aspekty ekologiczne i prawnopolityczne. Catallaxy, 2(2): 71-81. doi:10.24136/cxyv2i2.2.

\title{
Bezpieczeństwo energetyczne Polski w latach 2010-2015: aspekty ekologiczne i prawno-polityczne
}

\author{
ADAM POGORZELSKI \\ Uniwersytet Mikotaja Kopernika w Toruniu, Wydział Nauk Ekonomicznych i Zarzadzania, ul. Gagarina 13a, \\ 87-100 Toruń, Polska \\ వadampogorzelski310@gmail.com \\ (D) orcid.org/0000-0002-3285-8402
}

\begin{abstract}
Abstrakt
Motywacja: Kwestia energetyki jest przedmiotem nieustannie powracających debat politycznych, co uwarunkowane jest w znacznej mierze brakiem porozumienia w kwestii właściwego kierunku jej rozwoju. Bezpieczeństwo energetyczne jest kwestią złożoną, której analiza wymaga, poza aspektami ekonomicznymi, uwzględnienia także aspektów środowiskowych oraz prawno-politycznych. Chęć oceny związku między aktualną sytuacją energetyczną Polski a bezpieczeństwem energetycznym oraz jego potencjalnych skutków w kontekście przytoczonych aspektów była głównym motywem wyboru tematyki niniejszego artykułu.

Cel: Celem artykułu jest ukazanie związku między wykorzystaniem konwencjonalnych i odnawialnych źródeł energii a bezpieczenstwem energetycznym Polski w kontekście aspektów ekologicznych i prawno-politycznych.

Wyniki: Na podstawie przeprowadzonej analizy można wyciągnąć kilka wniosków. Po pierwsze, wysoki poziom zanieczyszczeń powietrza był wywołany w znacznym stopniu niekorzystną strukturą źródeł energii. Po drugie, wykazano konflikt interesów między polską polityką energetyczną, opartą na węglu a niskoemisyjną polityką Unii Europejskiej (UE). Po trzecie, wykazano zależność między działaniami rządowymi a znacznym spowolnieniem rozwoju energetyki odnawialnej w Polsce, co może w przyszłości skutkować negatywnymi konsekwencjami.
\end{abstract}

Stowa kluczowe: bezpieczeństwo energetyczne; konwencjonalne źródta energii; energetyka JEL: Q42; Q48; Q50; Q54; Q58

\section{Wprowadzenie}

Bezpieczeństwo energetyczne jest zagadnieniem, które można rozważać wieloaspektowo. Ekonomiczna perspektywa nie jest wystarczająca, by móc za jej pomocą dokonać oceny stopnia bezpieczeństwa energetycznego danego państwa. Pozostałymi, istotnymi kwestiami są: uwarunkowania prawno-polityczne znacznie wpływające na wytwarzanie i wykorzystanie energii oraz oddziaływanie krajowej energetyki na środowisko naturalne. Dopiero po dokonaniu syntezy oraz analizy powyższych aspektów w analizowanym okresie oraz po uwzględnieniu możliwych skutków sytuacji energetycznej omawianej gospodarki w przyszłości, można w trafny sposób ocenić sytuację energetyczną państwa.

Celem artykułu jest ukazanie związku między wykorzystaniem konwencjonalnych i odnawialnych źródeł energii a bezpieczeństwem 
energetycznym Polski w kontekście aspektów ekologicznych i prawno-politycznych.

W niniejszym artykule dokonano przeglądu i prezentacji najważniejszych zagadnień, związanych $z$ bezpieczeństwem energetycznym Polski w ostatnich latach $w$ kontekście uwarunkowań ekologicznych oraz prawno-politycznych. Analizę uzupełniono o aktualne dane oraz skoncentrowano się na ocenie mocnych i słabych stron polskiej polityki energetycznej w analizowanym okresie.

W Sekcji 2. dokonano przeglądu literatury. W Sekcji 3. przedstawiono wykorzystane metody badawcze. W Sekcji 4. dokonano analizy aspektów ekologicznych i prawno-politycznych bezpieczeństwa energetycznego Polski w analizowanym okresie. W Sekcji 5. zaprezentowano wnioski $z$ przeprowadzonej analizy.

Zakres czasowy niniejszego artykułu stanowią lata 2010-2015 ze względu na ograniczoną dostępność danych z lat 2016-2017.

\section{Przegląd literatury}

Informacje i dane związane z tematyką energetyki i bezpieczeństwa energetycznego są obecnie latwo dostępne. Roczne raporty dotyczące wielkości ekonomicznych z zakresu energetyki są udostępniane m.in. przez BP (2017) oraz GUS (2012a-2016a). Wykorzystano je w celu zobrazowania sytuacji energetycznej w Polsce. IEA (2017), przedstawia dane dotyczące zanieczyszczeń wywołanych przez energetykę oraz przygotowuje raporty dotyczące bezpieczeństwa energetycznego poszczególnych państw. Na podstawie przytoczonych informacji ukazano stopień emisyjności gospodarki na tle innych państw, a także podkreślono potrzebę modernizacji polskiej energetyki.

Istnieje także wiele publikacji związanych $z$ omawianą tematyką. J. Trzeszczyński (2015), dokonał analizy Projektu Polityki energetycznej Polski do 2050 r. (tzw. PEP 2050). Wykorzystano ją w celu przedstawienia słabych stron przytoczonego projektu.

C.T. Szyjko (2011), zwrócił uwagę na problem związany z brakiem konsekwencji zwią- zanych ze zbyt powolnym realizowaniem polityki energetycznej Polski. Argumentację tę wykorzystano w celu wyjaśnienia przyczyn braku regularnych działań związanych $z$ realizacją analizowanej polityki.

P. Górski (2017), podjął temat problemu zanieczyszczonego powietrza w Polsce, który wciąż pozostaje nierozwiązany. Na podstawie tej analizy wytłumaczono główną przyczynę znacznego zanieczyszczenia powietrza w Polsce oraz skutki z nim związane.

W przytoczonych publikacjach skoncentrowano się na różnych kwestiach bezpieczeństwa energetycznego Polski w kontekście aspektów przyrodniczych i prawno-politycznych $w$ analizowanym okresie. W literaturze przedmiotu brakuje publikacji dotyczących wszystkich, omówionych kwestii, co stanowi lukę poznawczą. W niniejszym artykule dokonano syntezy aktualnego stanu wiedzy w zakresie najważniejszych kwestii bezpieczeństwa energetycznego Polski w latach 2010-2015 w kontekście uwarunkowań przyrodniczych i prawno-politycznych.

\section{Metody}

W części teoretycznej artykułu wykorzystano analizę opisową i porównawczą. W części empirycznej zastosowano analizę wskaźnikową, w której posłużono się wskaźnikiem emisyjności gospodarki.

\section{Wyniki badania}

\subsection{Kwestie ekologiczne wytwarzania energii w Polsce}

$Z$ pozyskiwaniem energii wiążą się liczne konsekwencje dla środowiska naturalnego. Przyczyną tego jest m.in. emisja zanieczyszczeń wywołana spalaniem surowców potrzebnych do uzyskania energii. $\mathrm{Na}$ ilość emitowanych substancji przez gospodarkę wpływa kilka aspektów. Należą do nich m.in.: energochłonność gospodarki, struktura źródeł pozyskiwa- 
nej energii oraz technologie, dzięki którym można minimalizować emisję.

Wielkość emisji $\mathrm{CO}_{2}$ do atmosfery przez gospodarkę jest niezwykle istotna ze względu na postępujący proces efektu cieplarnianego. Mimo, że początkowe ograniczanie emisji może sprawiać wrażenie ekonomicznie nieuzasadnionego, pod względem ekologicznym jest niezwykle ważne, gdyż oznacza to minimalizowanie negatywnych skutków nieodpowiedzialnej działalności człowieka, które mogą wystąpić w przyszłości przynosząc niewymierne straty.

W latach 2010-2014 całkowita ilość $\mathrm{CO}_{2}$, emitowana przez polską gospodarkę stopniowo malała z poziomu około $300 \mathrm{mln}$ do 279 $\mathrm{mln}$ ton. Do trzech największych źródeł emisji należały kolejno: węgiel $(70,0 \%)$, ropa naftowa (20,0\%) i gaz ziemny (8,5\%). Pozostałe źródła stanowiły zaledwie 1,0\% całkowitej emisji do atmosfery (IEA, 2016).

Analiza całkowitej produkcji $\mathrm{CO}_{2} \mathrm{w}$ gospodarce nie daje jednak podstaw do dokonania dokładnego porównania emisyjności na tle innych państw ze względu na różnice w wielkościach gospodarek. W celu bardziej miarodajnego zobrazowania poziomu emisji $\mathrm{CO}_{2}$ w Polsce posłużono się wskaźnikiem emisyjności gospodarki $\left(E_{t}\right)$, którego poziom dla analizowanych lat przedstawiono na wykresie 1. Wskaźnik obliczono według wzoru (1):

$$
E_{t}=\mathrm{Co}_{2 t} / \mathrm{PKB}_{t},
$$

gdzie:

$\mathrm{CO}_{2 t}$ - całkowita emisja $\mathrm{CO}_{2}$ w okresie $t$;

$P K B_{t}-\mathrm{PKB}$ danego państwa w okresie $t$. Im mniejszy poziom wskaźnika, tym niższa emisyjność omawianej gospodarki.

$\mathrm{Na}$ podstawie danych zaprezentowanych na wykresie 1. można zaobserwować stopniową redukcję emisji $\mathrm{CO}_{2}$, której wielkość w 2010 r. wynosiła 0,39 i malała w analizowanym okresie do poziomu 0,31.

Analizę emisyjności Polski warto także uzupełnić o porównanie $z$ innymi państwami. Polskę, podobnie jak większość państw bloku wschodniego, cechowała relatywnie wysoka emisyjność. Wynikało to w dużej mierze ze struktury źródeł pozyskiwanej energii. Do państw o wyższej emisyjności w 2014 r. można zaliczyć: Białoruś $(0,36)$, Ukrainę $(0,68)$, Rosję $(0,46)$, Czechy $(0,33)$. Państwami o niższej emisyjności były m.in.: Niemcy $(0,21)$, Szwecja $(0,09)$, Norwegia $(0,11)$, Francja $(0,12)$, Hiszpania $(0,16)$ (IEA, 2016).

$\mathrm{Na}$ podstawie przytoczonych informacji można stwierdzić, że polska gospodarka była $\mathrm{w}$ analizowanym okresie o wiele bardzie emisyjna od pozostałych, rozwiniętych gospodarek europejskich. Oznacza to potrzebę inwestowania $\mathrm{w}$ energetykę $\mathrm{w}$ celu wyrównania poziomu emisji Polski i europejskich państw rozwiniętych.

Mimo, że Polska położona jest $\mathrm{w}$ miejscu o względnie niskim ryzyku klęsk żywiołowych, to postępujący efekt cieplarniany, wywołany nadmierną obecnością $\mathrm{CO}_{2} \mathrm{w}$ atmosferze, w przyszłości może być przyczyną znacznych strat $\mathrm{w}$ energetyce. Związane $z$ nim, częstsze występowanie skrajnych warunków pogodowych, takich, jak huragany, może w przyszłości zwiększać ryzyko uszkodzeń linii przesyłowych, co może skutkować utrudnieniem dostępu do energii elektrycznej. Zwiększona zmienność opadów może powodować powodzie i susze, co potencjalnie będzie się przekładać na utrudnienia $\mathrm{w}$ funkcjonowaniu elektrowni wymagających znacznych ilości wody. Rosnące temperatury, zwiększające parowanie wód powierzchniowych oraz zaburzające gospodarkę wodną, mogą negatywnie wpłynąć na rośliny wykorzystywane w celach opałowych. Wraz z globalnym ociepleniem, należy się też spodziewać pogorszenia warunków wiatrowych (długie, bezwietrzne okresy na przemian $z$ huraganami) (Ministerstwo Środowiska, 2012, ss. 26-27).

Stopniowa redukcja emisji $\mathrm{CO}_{2} \mathrm{w}$ gospodarce była korzystna dla bezpieczeństwa energetycznego, nie tylko ze względu na minimalizację zagrożeń związanych $z$ zanieczyszczaniem środowiska, lecz także $z$ powodu wymogów legislacyjnych, które omówiono szerzej w Sekcji 4.2.

Kolejnym problemem, związanym ze środowiskiem były szeroko pojęte zanieczyszczenia powietrza, które są także szkodliwe dla człowieka. Wywołane były one także 
w dużej mierze przez gospodarstwa domowe, w których nieodpowiedzialnie wykorzystywano niskiej jakości materiały opałowe, a także przestarzałe piece (Górski, 2017).

$\mathrm{Na}$ wykresie 2. przedstawiono liczbę zgonów spowodowaną zanieczyszczeniami powietrza $\mathrm{w}$ Polsce i wybranych państwach w 2016 r. Można zaobserwować wysoki poziom śmiertelności spowodowanej zanieczyszczeniami na tle wielu państw lepiej rozwiniętych.

Według danych OECD (2017), ilość pyłów zawieszonych (PM2,5), których obecność jest szkodliwa dla człowieka, w 2010 r. wyniosła $28,2 \mu \mathrm{g} / \mathrm{m}^{3} 1$, a następnie zmalała do wielkości 23,4 $\mu \mathrm{g} / \mathrm{m}^{3}$ w $2015 \mathrm{r}^{2}$.

Zgodnie z zaleceniami Światowej Organizacji Zdrowia (World Health Organization - WHO), dotyczącymi PM2,5, nie należy przekraczać górnej granicy stężenia tego zanieczyszczenia $w$ powietrzu wynoszącej $10 \mu \mathrm{g} / \mathrm{m}^{3}$ (WHO, 2017). Ponadto, według WHO (2016), trzydzieści trzy z pięćdziesięciu najbardziej zanieczyszczonych miast Unii Europejskiej (UE) było położonych w Polsce.

Zważywszy na fakt, że bezpieczeństwo energetyczne związane jest także $z$ energetyką przyjazną środowisku, należy stwierdzić, że mimo stopniowej redukcji emitowanych zanieczyszczeń, sytuacja Polski była wciąż niekorzystna.

\subsection{Aspekty prawno-polityczne wytwarzania energii w Polsce}

W celu dokonania trafnej analizy aspektów prawnych należy uwzględnić czynniki wewnętrzne i zewnętrzne kształtujące polską politykę energetyczną oraz otoczenie prawne.

W kontekście uwarunkowań prawno-politycznych, nakładanych przez UE, do największych zagrożeń $\mathrm{w}$ przyszłości należy potencjalne niesprostanie przez Polskę stawianym przez UE celom polityki klimatycznej. Polsce, której energetyka w analizowanym okresie opierała się głównie na węglu, oraz w której bardzo niechętnie odchodzi się od

\footnotetext{
$1 \mu g=10^{-9} \mathrm{~kg}$.

Dane za lata 2014-2015 zostały oszacowane.
}

tego surowca (GUS, 2012a-2016a), może być potencjalnie trudno sprostać przyszłym wymogom, związanym $z$ redukcją emitowanych zanieczyszczeń. Według danych IEA (2012, s. 65), polska, przestarzała technologicznie branża energetyczna będzie wymagała w latach 2010-2030 inwestycji wysokości $610 \mathrm{mld}$ PLN. Z przestarzałą technologią wiąże się wysoka emisyjność polskiej energetyki. Ponadto, zgodnie $z$ informacjami udostępnionymi przez Komisję Europejską, polska gospodarka $\mathrm{w}$ analizowanym okresie należała do najbardziej energochłonnych w UE (European Commission, 2016, ss. 217-231). Zbyt wygórowane cele, stawiane przez UE, którym Polska energetyka nie byłaby w stanie sprostać, mogłyby negatywnie oddziaływać na bezpieczeństwo energetyczne ze względu na nakładane sankcje. Można założyć, że cele polityki klimatycznej UE będą coraz trudniejsze do spełnienia.

Do najważniejszych dokumentów dotyczących energetyki państw członkowskich UE w analizowanych latach należy Dyrektywa 2009/28/WE (2009), zgodnie z którą udział energii z OZE w końcowym zużyciu energii brutto całej UE do 2020 r., miał znajdować na poziomie $20 \%$. Cel ten przydzielono na różnych poziomach dla poszczególnych państw. Dla Polski wyznaczono go na poziomie $15 \%$, co stanowiło cel relatywnie łatwy do osiągnięcia, względem pozostałych państw. Ponadto, każde państwo członkowskie zobligowane zostało do zapewnienia udziału energii z OZE $w$ transporcie na poziomie $10 \%$. Za niewywiązanie się z postawionych celów unijnej polityki klimatycznej, możliwe jest nałożenie kar pieniężnych na państwo członkowskie.

W związku z przedstawionymi informacjami, należy dokonać analizy stopnia, w jakim realizowane były w Polsce wymogi UE $w$ analizowanym okresie, ponieważ skuteczność tych działań miała istotny wpływ na bezpieczeństwo energetyczne Polski w latach następnych.

$\mathrm{Na}$ wykresie 3. przedstawiono procentowy udział OZE w końcowym wykorzystaniu energii brutto $w$ wybranych branżach w Polsce oraz w gospodarce ogółem. Na podstawie danych na wykresie 3. można wywnioskować, że tempo wzrostu udziału OZE było 
zbyt wolne. W analizowanym okresie wzrost ten wyniósł około 2,5 p.p., osiągając w 2015 r. poziom $11,77 \%$. Ponadto, najwolniejsze tempo wzrostu przypada na ostatnie trzy lata analizowanego okresu. W przypadku udziału OZE w transporcie, sytuacja Polski była jeszcze bardziej niekorzystna, ponieważ poziom opisywanego wskaźnika wahał się bez wyraźnego trendu wzrostowego.

W kontekście uwarunkowań prawnych należy także wspomnieć o Ustawie o inwestycjach $w$ zakresie elektrowni wiatrowych (2016). W jej treści uregulowano minimalną odległość, która powinna dzielić elektrownie wiatrowe oraz m.in. budynki mieszkalne. Odległość ta, zgodnie $z$ ustawą, nie może być mniejsza od dziesięciokrotności wysokości elektrowni wiatrowej. Wprowadzenie ustawy skutecznie ograniczyło przestrzeń, w której można dokonać budowy elektrowni, co przełożyło się na znaczny spadek inwestycji w energetykę wiatrową $w$ Polsce. Zgodnie z danymi zaprezentowanymi na wykresie 4., w 2017 r. moc zainstalowana elektrowni wiatrowych wzrosła jedynie o około 17,01 MW rok do roku. Wielkość ta stanowi 1,39\% przyrostu mocy z 2016 r. Tak znaczący spadek inwestycji w elektrownie oparte na energii wiatru jest niekorzystny dla bezpieczeństwa energetycznego Polski, ponieważ energetyka wiatrowa była najbardziej dynamicznie rozwijanym OZE w Polsce $\mathrm{w}$ analizowanym okresie. Stagnacja, wywołana tzw. ustawą odległościową, znacznie zwiększa ryzyko niewywiązania się z zobowiązań w stosunku do UE, dotyczących udziału OZE $\mathrm{w}$ końcowym wykorzystaniu energii.

$\mathrm{Na}$ podstawie tych informacji można założyć, że Polska, przy tym tempie wzrostu udziału OZE, nie będzie w stanie spełnić postawionego celu, a więc tempo wzrostu $\mathrm{w}$ analizowanych latach było niewystarczające. Sytuacja ta była niekorzystna dla bezpieczeństwa energetycznego Polski ze względu na możliwe, wysokie kary pieniężne, nałożone przez UE za niewypełnienie postawionych celów. Sposobem na uniknięcie sankcji przez Polskę jest handel nadwyżkami OZE w UE, jednak $z$ zakupem nadwyżki także wiązałyby się wysokie koszty.
W 2013 r. został opublikowany przez Komisję Europejską komunikat Zielona Księga, w którym określono cele polityki klimatycznej UE do $2030 \mathrm{r}$. W treści dokumentu przedstawiono ramy polityki energetycznej UE, zgodnie $z$ którą powinny zostać spełnione m.in. następujące cele (European Commission, 2013, s. 3):

- redukcja emisji gazów cieplarnianych o $80-95 \%$ do 2050 r. oraz o $40 \%$ do 2030 r.; - większy udział OZE (30\% do 2030 r.);

- poprawiona efektywność energetyczna, a także lepsza infrastruktura;

- inwestycje w energetykę.

Zważywszy, że podstawą polskiej energetyki $w$ analizowanym okresie był węgiel, a polska branża energetyczna była przestarzała, należy zauważyć, że cele UE mogą być w przyszłości potencjalnie zbyt wygórowane dla Polski. W celu zwiększenia bezpieczeństwa energetycznego państwa, Polska powinna negocjować relatywnie niskie cele indywidualne.

Polityka energetyczna państwa ma istotny wpływ na kształtowanie bezpieczeństwa energetycznego. W sytuacji silnego, zewnętrznego wpływu polityki unijnej, ważne jest, w jakim stopniu cele danego państwa i UE są zbieżne oraz, w jaki sposób na siebie oddziałują, ponieważ sprzeczne i niespójne cele mogą być przyczyną utrudnień rozwoju energetyki.

Dokument opublikowany przez Ministerstwo Gospodarki (2009), pt. Polityka energetyczna Polski do 2030 roku, oparty został na polityce energetycznej UE. Uwzględniał on podpisany przez Polskę Pakiet klimatycznoenergetyczny, który zakładał (European Commission, 2016):

- redukcję emisji gazów cieplarnianych o 20\% do 2020 r. (w porównaniu do 1990 r.);

- 20\% udziału OZE w zużyciu energii w UE;

- wzrost efektywności energetycznej o $20 \%$. Głównymi kierunkami polskiej polityki energetycznej miały być:

- wzrost efektywności energetycznej,

- poprawa bezpieczeństwa dostaw surowców,

- wprowadzenie energetyki jądrowej,

- rozwój OZE, 
- zmniejszenie negatywnego wpływu na środowisko.

Mimo polityki energetycznej państwa $\mathrm{w}$ analizowanych latach, mającej na celu spetnianie zadań wyznaczanych przez UE, istniał problem braku spójnej, klarownej wizji polskiej energetyki, a także konsekwencji w spetnianiu jej założeń. Istotnym utrudnieniem wdrażania założonych zmian, był brak ponoszonych konsekwencji za niewywiązanie się z założeń dokumentu opublikowanego przez Ministerstwo Gospodarki (2009). Mogło to być przyczyną braku systematycznych dążeń do wypełnienia wyznaczonych deklaracji (Szyjko, 2011, ss. 312-313).

Ministerstwo Gospodarki (2014), przedstawiło także Projekt polityki energetycznej Polski do 2050 roku (tzw. PEP 2050). Postulowano w nim zrównoważony rozwój energetyki we wszystkich kierunkach, co miało doprowadzić do stopniowej dywersyfikacji paliw w Polsce. Ze względu na długoterminowość projektu, wyodrębniono w nim trzy scenariusze, w tym jeden, najbardziej prawdopodobny (zrównoważony), zgodnie z którymi polska energetyka będzie kształtowana. W scenariuszu zrównoważonym deklarowano 15-20\% udział poszczególnych nośników w bilansie energetycznym, oprócz paliw stałych, których wkład miał być dominujący. Założono również rozwój energetyki jądrowej oraz górnictwa, które miało być podstawą bezpieczeństwa energetycznego Polski. Uwzględniono także wymogi legislacyjne, nałożone przez UE.

Alternatywą dla przytoczonych celów jest scenariusz jądrowy, zgodnie $z$ którym nastąpi znaczący wzrost udziału atomu w wytwarzaniu energii. Założono 45-60\% udział tego paliwa $w$ bilansie energetycznym. Wkład węgla, ropy naftowej i gazu ziemnego oszacowano na poziomie $10-15 \%$, natomiast OZE $-15 \%$.

Ostatnią z zakładanych koncepcji jest scenariusz gaz+OZE. Zgodnie $z$ tym planem, polski bilans energetyczny będzie zdominowany przez gaz ziemny oraz OZE. Ich łączny udział wyniesie około 50-55\%. Wkład węgla i ropy naftowej do bilansu energetycznego wyniesie odpowiednio $30 \%$ i $15-20 \%$. W scenariuszu założono udział OZE na poziomie co najmniej równym 20\%, zaś energii jądrowej - około $12 \%$.

Do głównych zarzutów, wysuwanych pod adresem PEP 2050 można zaliczyć (Trzeszczyński, 2015, ss. 4-6):

- zbytnią ogólnikowość - nie przedstawiono konkretnych danych oraz rzetelnych wyliczeń, na podstawie których podejmowane były decyzje dotyczące PEP 2050 oraz nie sprecyzowano działań mających na celu spełnienie założeń dokumentu;

- swobodne potraktowanie danych statystycznych - wiele zamieszczonych danych było nieaktualnych;

- małe prawdopodobieństwo wykonania scenariuszy alternatywnych - koncepcja energii atomu jest niezwykle kosztowna. Ponadto, wymagałaby importowania nośników energetycznych z zagranicy, co skutkowałoby uzależnieniem od innych państw. W przypadku scenariusza $g a z+O Z E$, opartego na wykorzystaniu złóż gazu niekonwencjonalnego, istnieje problem $z$ oceną realności jego wykonania, ponieważ w okresie publikowania dokumentu nie możliwe było dokonanie dokładnego pomiaru wielkości złóż gazu niekonwencjonalnego na terenie Polski oraz precyzyjnej analizy kosztów wydobycia;

- brak działań mających na celu aktywne kreowanie polityki klimatyczno-energetycznej UE.

Warto podkreślić, że najbardziej prawdopodobny scenariusz zakładał udział OZE na poziomie około $15 \%$ do 2050 r., co oznacza względnie ograniczony rozwój energii odnawialnej w Polsce. Może mieć to negatywny wpływ na polską gospodarkę, ze względu na postępujące wymogi legislacyjne UE. W PEP 2050 założono rozwój technologii ograniczających emisję gazów cieplarnianych ze spalania węgla. Jeżeli technologia nie zostanie dostatecznie rozwinięta, wówczas możliwe będzie nałożenie kar finansowych przez UE na Polskę. Należy także zadać pytanie, na ile rozsądna jest długoterminowa polityka opierania energetyki na surowcu, z którego wyko- 
rzystaniem wiąże się tak wiele negatywnych efektów oraz którego wykorzystanie na całym świecie w ostatnich latach maleje na korzyść innych źródeł energii (BP, 2017).

W kontekście aspektów prawnych nie można pominąć Ustawy o OZE (2015), uchwalonej 28.01.2015 przez Sejm, której projekt był opracowywany przez ponad trzy lata. Jej celem był zrównoważony rozwój energetyki odnawialnej. Zgodnie z treścią ustawy, właściciele mikroinstalacji mogli sprzedawać energię korzystając z systemu taryf gwarantowanych przez okres 15 lat. Ustanowiono także system aukcyjny, który wprowadzono w styczniu 2016 r. Za jego pomocą umożliwiono sprzedaż energii po najniższej cenie. W czerwcu 2016 r. dokonano nowelizacji omawianej ustawy. Zmodyfikowano system aukcyjny, w którym zwiększono wsparcie dla współspalania węgla i biomasy. Sprecyzowano definicję prosumenta, który zgodnie $z$ treścią ustawy, nie powinien odnosić korzyści finansowych z produkcji energii. $Z$ tego powodu, zamiast systemu taryf gwarantowanych, zaproponowano system opustów na energię, który polegał na przyznaniu prawa prosumentom do części nadwyżki energii oddanej do sieci. Wprowadzenie ustawy pozytywnie wpływało na bezpieczeństwa energetycznego Polski, ponieważ określała ona poziom wsparcia dla OZE. Było to korzystne dla inwestorów, ponieważ nie byli zmuszeni prowadzić działalności $w$ warunkach niepewności legislacyjnych. Pozytywną zmianą $w$ nowelizacji ustawy było rozszerzenie definicji prosumenta, którym, od tej pory, mogły zostać nie tylko osoby fizyczne. Do negatywnych stron wprowadzania ustawy należy zaliczyć przesunięcie $\mathrm{w}$ czasie wprowadzenia systemu aukcyjnego, ponieważ powodowało to pogorszenie sytuacji mniejszych podmiotów, których inwestycje były odpowiednio przygotowane do nowego systemu wsparcia OZE, a także wsparcie dla współspalania węgla i biomasy, które trudno traktować jako technologię odnawialną (IEA, 2017; Gramwzielone.pl; 2016).

\section{Zakończenie}

$Z$ analizy aspektów ekologicznych wynika kilka niekorzystnych dla Polski wniosków. Po pierwsze, Polska należała do grona gospodarek o wysokim współczynniku emisyjności $\mathrm{CO}_{2}$ w UE. Spowodowane to było $w$ dużej mierze strukturą konsumowanej energii, w której przeważał węgiel. Warto jednak podkreślić, że w latach 2010-2014 poziom wskaźnika malał, co oznaczało stopniową poprawę. Po drugie, w kontekście czynników ekologicznych, należy także przywołać problem wysokiego poziomu zanieczyszczenia powietrza. Było to powodem wielu, poważnych chorób oraz przyczyną skrócenia przeciętnej długości życia w Polsce.

Uwarunkowania prawno-polityczne dotyczące Polski w analizowanym okresie, można podzielić na zewnętrzne i wewnętrzne. Pierwsze $z$ nich dotyczyły polityki klimatyczno-energetycznej UE, której celem było stworzenie gospodarki niskoemisyjnej, w jak najmniejszym stopniu ingerującej $\mathrm{w}$ środowisko. Uwarunkowania wewnętrzne dotyczyły polityki energetycznej Polski. Była ona próbą połączenia wymogów unijnych oraz interesów Polski, której głównym celem było zachowanie dominującej roli węgla $w$ energetyce. Poważnym problemem był brak konsekwencji w realizacji celów polityki energetycznej oraz spowolnienie rozwoju energetyki odnawialnej w ostatnich latach, czego przykładem może być zbyt powolne tempo wzrostu udziału OZE w końcowym wykorzystaniu energii brutto $w$ analizowanym okresie. Może to w przyszłości skutkować karami finansowymi, nałożonymi przez UE. Na podstawie tych informacji można wysnuć wniosek, że wiele działań na rzecz ochrony środowiska naturalnego w Polsce, była raczej głównie wywołana wymogami unijnymi, niż chęcią przeciwdziałania negatywnym skutkom działalności człowieka, co może w przyszłości skutkować poważnymi konsekwencjami.

Podsumowując, należy zauważyć korzystne działania, których celem było zwiększenie bezpieczeństwa energetycznego Polski. Jednak należy także podkreślić problem nad- 
miernego przywiązania do węgla oraz wciąż istniejącego dystansu w świadomości ekologicznej między rozwiniętymi państwami Europy a Polską.

\section{Bibliografia}

BP. (2017). Statistical review of world energy. Pobrane 28.09.2017 z http://www.bp.com.

Dyrektywa Parlamentu Europejskiego i Rady 2009/28/WE z dnia 23 kwietnia 2009 r. w sprawie promowania stosowania energii ze źródeł odnawialnych zmieniająca $\mathrm{i} w$ następstwie uchylająca dyrektywy 2001/77/WE oraz 2003/30/WE (Dz.Urz. UE OJ L 140).

European Commission. (2013). Zielona ksiega. Ramy polityki w zakresie klimatu i energii do roku 2030. Pobrane 20.05.2017 z https://www.mos.gov.pl.

European Commission. (2016). EU energy in figures. Statistical pocketbook 2016. Pobrane $\mathrm{z}$ https:// ec.europa.eu.

Górski, P. (2017). Brudne powietrze zabija w Polsce 140 osób dziennie. Pobrane 18.05.2017 z http:// www.rp.pl.

Gramwzielone.pl. (2016). Sejm przyjat nowelizacje ustawy o OZE. Co teraz? Pobrane 05.06.2017 $z$ http://gramwzielone.pl.

GUS. (2012a-2016a). Gospodarka paliwowo-energetyczna w latach 2010-2015. Pobrane 01.04.2017 $z$ http://stat.gov.pl.

GUS. (2016b). Energia ze źródet odnawialnych $w$ latach w 2015 roku. Pobrane 26.04.2017 z http:// stat.gov.pl.

IEA. (2012). Energy policies of IEA countries. Poland 2011 review. Pobrane 20.05.2017 $\mathrm{z}$ https:// www.iea.org.

IEA. (2016). $\mathrm{CO}_{2}$ emissions from fuel combustion. Pobrane 12.05.2017 z https:/ /www.iea.org.

IEA. (2017). Energy policies of IEA countries. Poland. 2016 review. Pobrane 03.04.2017 $\mathrm{z}$ https:// www.iea.org.

IHME. (2017). Pobrane 30.09.2017 z http://www. healthdata.org.

Ministerstwo Gospodarki. (2009). Polityka energetyczna Polski do 2030 roku. Pobrane 19.05.2017 z http://www.me.gov.pl.
Ministerstwo Gospodarki. (2014). Projekt polityki energetyczna Polski do 2050 roku. Pobrane 19.05.2017 z http://bip.me.gov.pl.

Ministerstwo Środowiska. (2012). Strategiczny plan adaptacji dla sektorów i obszarów wrażliwych na zmiany klimatu do roku 2020 z perspektywa do roku 2030. Pobrane 14.01.2018 z https://www. mos.gov.pl.

OECD. (2017). Pobrane 18.05.2017 z http://stats. oecd.org.

Pogorzelski, A. (2017). Konwencjonalne i odnawialne źródła energii a bezpieczeństwo energetyczne Polski w latach 2010-2015. Nieopublikowana praca licencjacka. Uniwersytet Mikołaja Kopernika, Toruń.

Szyjko, C.T. (2011). Wybrane problemy bezpieczeństwa energetycznego Europy. Studium ekonomiczno-prawne. Piotrków Trybunalski: Wydawnictwo UJK.

Trzeszczyński, J. (2015). Komentarz do Projektu Polityki Energetycznej Polski do 2050 r. Energetyka, 123(6).

Ustawa z dnia 20 lutego 2015 r. o odnawialnych źródłach energii (Dz.U. 2015 poz. 478).

Ustawa $z$ dnia 20 maja 2016 roku o inwestycjach w zakresie elektrowni wiatrowych (Dz. Urz. 2016 poz. 961).

WHO. (2016). Ambient air pollution database. Pobrane 18.05.2017 z http://www.who.int.

WHO. (2017). Pobrane 18.05.2017 z http://www. who.int.

Informacje uzupełniające

Wkład autorski: autor zaakceptował ostateczną wersję artykułu.

Źródła finansowania: artykuł został w całości sfinansowany ze środków własnych autora.

Uwagi: wyniki badania były zaprezentowane $\mathrm{w}$ innej formie, tj. pracy licencjackiej Pogorzelski (2017). 
Aneks

Wykres 1.

Wskaźnik emisyjności CO2 w Polsce w latach 2010-2014

0,41

0,39

0,39

0,37

0,35

0,33

0,31

0,29

0,27

0,25

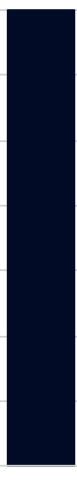

0,36

0,35
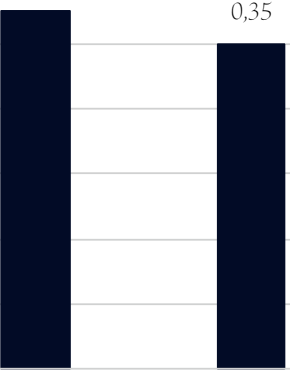

0,34

2010

2011

2012

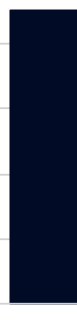

0,31

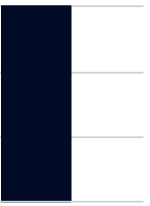

2013

2014

Uwagi:

Zakres czasowy ograniczono ze względu na dostępność danych.

Źródło: Opracowanie własne na podstawie IEA (2016).

Wykres 2.

Liczba zgonów spowodowana zanieczyszczeniami powietrza w Polsce i wybranych państwach OECD w 2016 r. (na 100 tys. mieszkańców)

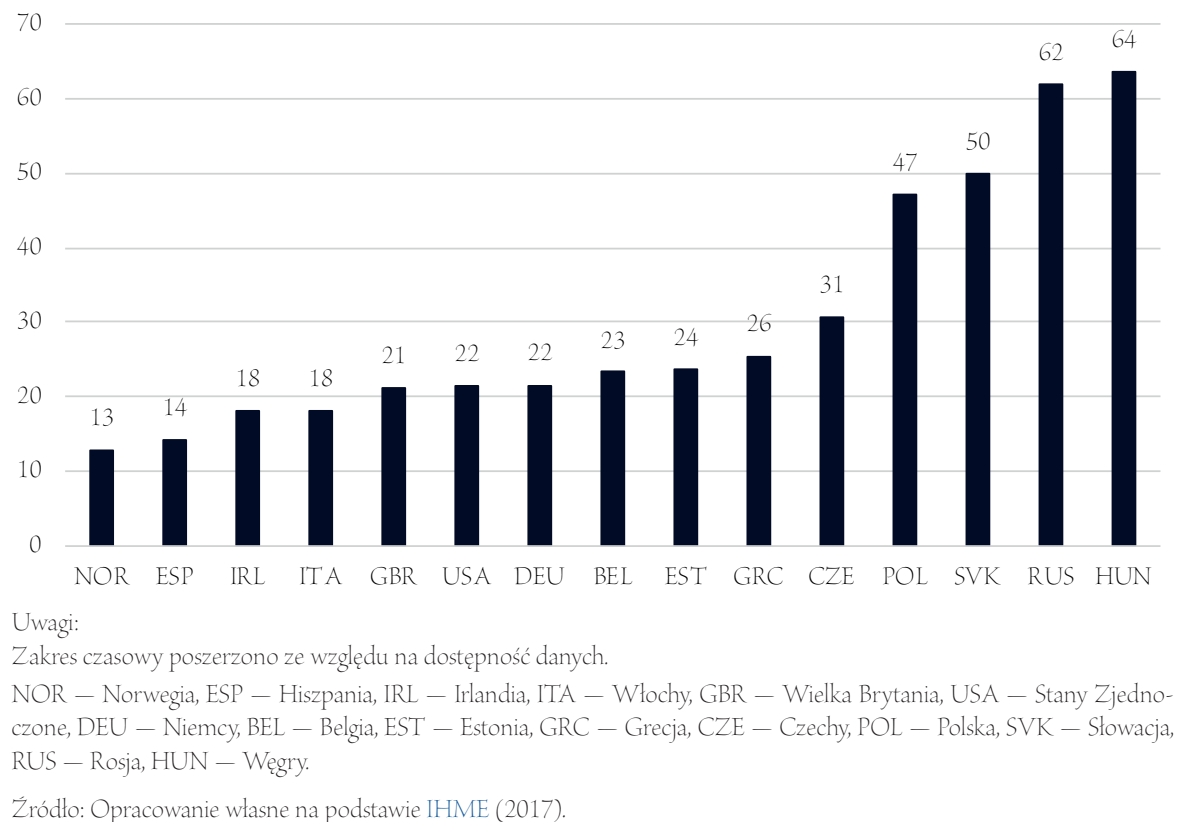


Wykres 3.

Udział OZE w końcowym zużyciu energii brutto ogółem oraz w poszczególnych branżach w Polsce w latach $2010-2015$ (w\%)

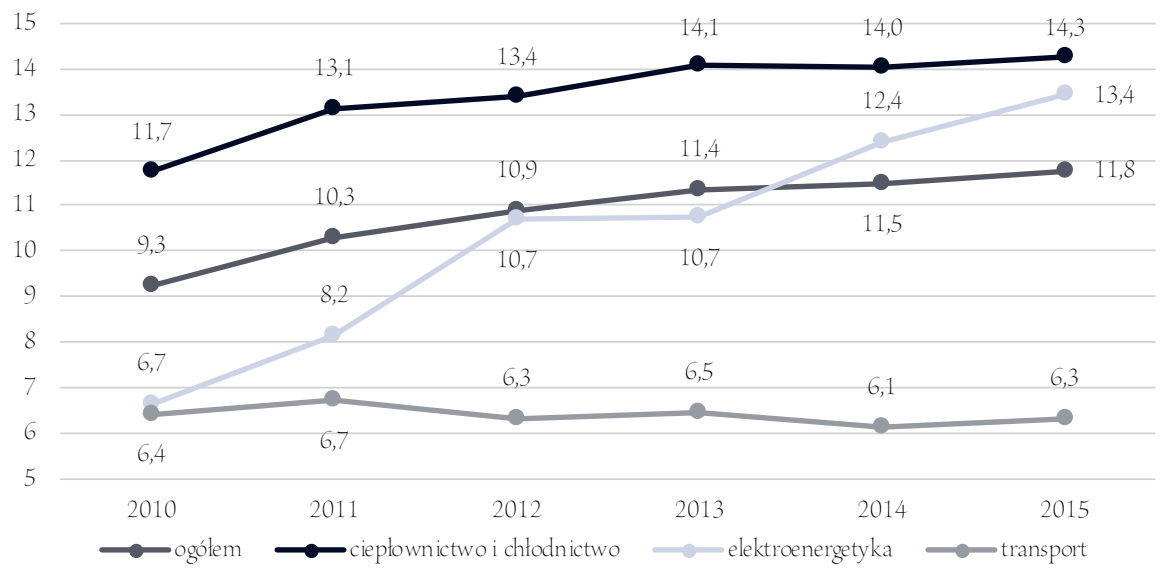

Źródło: Opracowanie własne na podstawie GUS (2016b).

Wykres 4.

Moc zainstalowana elektrowni (MW) wykorzystujących energię wiatru według stanu na 30.06.2017 w latach 2010-2017

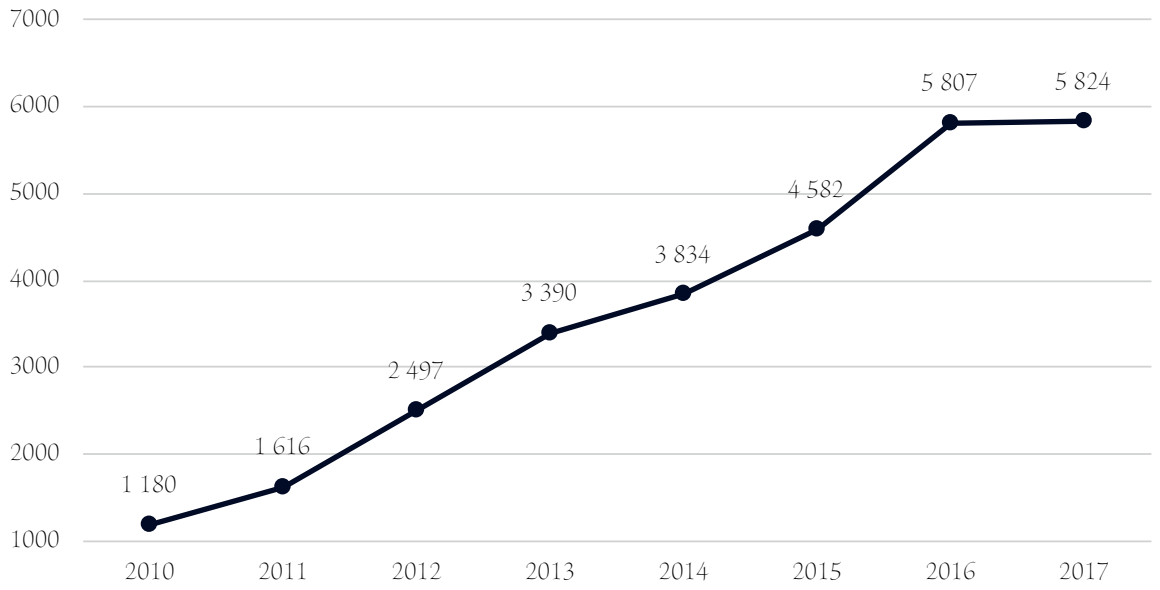

Źródło: Opracowanie własne na podstawie URE (2017). 
Poland's energy security in 2010-2015: ecological, legal and political aspects

\section{Abstract}

Motivation: The issue of energy security is the subject of constantly recurring political debates. It is caused by the lack of agreement on the proper direction of energy production development. Energy security is a complex issue, the analysis of which requires, in addition to economic aspects, environmental, legal and political considerations. The desire to assess the relationship between the current energy situation and the Polish energy security and the desire to assess its potential effects in the context of the listed aspects was the main reason for choosing the subject of this article.

Aim: The aim of this paper is to present the relationship between the use of conventional and renewable energy sources and Poland's energy security in the context of environmental, legal and political aspects.

Results: Several conclusions can be drawn from this analysis. Firstly, the high level of air pollution was caused by a very unfavorable structure of energy sources. Secondly, there was a conflict of interest between the Polish coal-based energy policy and the EU's low carbon policy. Thirdly, the relationship between governmental activities and a significant slowdown in the development of renewable energy in Poland has been demonstrated, which may have negative consequences in the future.

Keywords: energy security; conventional energy sources; renewable energy sources; energetics JEL: Q42; Q48; Q50; Q54; Q58 
